\title{
Mg/O2 Battery Based on the Magnesium-Aluminum Chloride Complex (MACC) Electrolyte
}

Vardar, Galin; Smith, Jeffrey G.; Thomson, Travis; Inagaki, Kouji; Naruse, Junichi; Hiramatsu, Hidehiko; Sleightholme, Alice E. S.; Sakamoto, Jeff; Siegel, Donald Jason; Monroe, Charles W.

Published in:

Chemistry of Materials

Link to article, DOI:

10.1021/acs.chemmater.6b02488

Publication date:

2016

Document Version

Peer reviewed version

Link back to DTU Orbit

Citation (APA):

Vardar, G., Smith, J. G., Thomson, T., Inagaki, K., Naruse, J., Hiramatsu, H., Sleightholme, A. E. S., Sakamoto, J., Siegel, D. J., \& Monroe, C. W. (2016). Mg/O Battery Based on the Magnesium-Aluminum Chloride Complex (MACC) Electrolyte. Chemistry of Materials, 28(21), 7629-7637. https://doi.org/10.1021/acs.chemmater.6b02488

\section{General rights}

Copyright and moral rights for the publications made accessible in the public portal are retained by the authors and/or other copyright owners and it is a condition of accessing publications that users recognise and abide by the legal requirements associated with these rights.

- Users may download and print one copy of any publication from the public portal for the purpose of private study or research.

- You may not further distribute the material or use it for any profit-making activity or commercial gain

- You may freely distribute the URL identifying the publication in the public portal 


\title{
$\mathrm{AMg} / \mathrm{O}_{2}$ Battery Based on the MACC Electrolyte
}

\author{
Gulin Vardar, ${ }^{\dagger}$ Jeffrey G. Smith, ${ }^{\ddagger}$ Travis Thompson, ${ }^{\ddagger}$ Kouji Inagaki, ${ }^{\S}$ Junichi Naruse,, Hidehiko Hiramatsu, ${ }^{\S}$ \\ Alice E. S. Sleightholme, ${ }^{\beta}$ Jeff Sakamoto, ${ }^{\ddagger}$ Donald J. Siegel, ${ }^{*,+,+,}$ and Charles W. Monroe ${ }^{*, \nabla}$ \\ ${ }^{\dagger}$ Materials Science and Engineering Department, ${ }^{\ddagger}$ Mechanical Engineering Department, and ${ }^{\circledR}$ Chemical Engineering Department, \\ University of Michigan, Ann Arbor, MI 48109, USA \\ ${ }^{\S}$ Research Laboratories, DENSO CORPORATION, 500-1, Minamiyama, Komenoki-cho, Nisshin, 470-0111, Japan \\ "North America Research \& Development, DENSO International America, Inc., 24777 Denso Drive, Southfield, MI 48086, USA \\ "Department of Energy Conversion and Storage, Technical University of Denmark, Fysikvej, Building 309, 2800 Kgs Lyngby, Den- \\ mark \\ ${ }^{\nabla}$ Department of Engineering Science, University of Oxford, Parks Road, Oxford, OX1 3PJ, UK
}

\begin{abstract}
Mg} / \mathrm{O}_{2}$ cells employing a $\mathrm{MgCl}_{2} / \mathrm{AlCl}_{3} / \mathrm{DME}$ (MACC/DME) electrolyte are cycled and compared to cells with modified Grignard electrolytes, showing that performance of magnesium/oxygen batteries depends strongly on electrolyte composition. Discharge capacity is far greater for MACC/DME-based cells, while rechargeability in these systems is severely limited. The $\mathrm{Mg} / \mathrm{O}_{2}-\mathrm{MACC} / \mathrm{DME}$ discharge product comprises a mixture of $\mathrm{Mg}\left(\mathrm{ClO}_{4}\right)_{2}$ and $\mathrm{MgCl}_{2}$, with the latter likely formed from slow decomposition of the former. The presence of $\mathrm{Cl}$ in these compounds suggests that the electrolyte participates in the cell reaction, or reacts readily with the initial electrochemical products. A rate study suggests that $\mathrm{O}_{2}$ diffusion in the electrolyte limits discharge capacities at higher currents. Formation of an insulating product film on the positive electrodes of $\mathrm{Mg} / \mathrm{O}_{2}-\mathrm{MACC} / \mathrm{DME}$ cells following deep discharge increases cell impedance substantially, and likely explains the poor rechargeability. An additional impedance rise consistent with film formation on the Mg negative electrode suggests the presence of detrimental $\mathrm{O}_{2}$ crossover. Minimizing $\mathrm{O}_{2}$ crossover and bypassing charge transfer through the discharge product would improve battery performance.
\end{abstract}

\section{INTRODUCTION}

Magnesium is an attractive negative-electrode material for battery applications due to its low cost, high energy density, and relative safety in comparison to alkali metals such as lithium. ${ }^{1-10}$ Furthermore, across the many possible 'metal/air' battery chemistries, the theoretical energy density provided by reacting $\mathrm{Mg}$ with $\mathrm{O}_{2}$ is among the highest. ${ }^{11-12}$ These advantages prompted the study of primary $\mathrm{Mg} /$ air batteries using aqueous electrolytes as early as the 1970s. ${ }^{13-17}$ Despite decades of study since, several challenges remain. ${ }^{18}$ For example, aqueous electrolytes corrode $\mathrm{Mg}$ electrodes because $\mathrm{Mg}$ reacts with $\mathrm{H}_{2} \mathrm{O}$ spontaneously to form passivating $\mathrm{Mg}(\mathrm{OH})_{2}$ on the electrode surface. ${ }^{19}$ Thus $\mathrm{Mg} /$ air batteries usually exhibit high interfacial impedance, making practical energy density at most a tenth of what theory suggests. ${ }^{20}$ Also, the use of air as an $\mathrm{O}_{2}$ source introduces pernicious impurities such as $\mathrm{CO}_{2}$.

Relatively few studies have explored the possibility of a rechargeable $\mathrm{Mg} / \mathrm{O}_{2}$ cell based on a non-aqueous electrolyte and a pure $\mathrm{O}_{2}$ gas source. Shiga et al. reported non-aqueous $\mathrm{Mg} / \mathrm{O}_{2}$ cells that operate at elevated temperatures. ${ }^{21-22}$ The electrolytes employed included simple $\mathrm{Mg}$ salts such as $\mathrm{Mg}\left(\mathrm{ClO}_{4}\right)_{2}$ and $\mathrm{Mg}\left(\mathrm{N}\left(\mathrm{SO}_{2} \mathrm{CF}_{3}\right)_{2}\right)_{2}$ dissolved in organic solvents or ionic liquids. Due to their propensity for forming $\mathrm{Mg}^{2+}$-impermeable passivation layers, it remains a matter of debate whether these electrolytes are compatible with $\mathrm{Mg}$ metal. ${ }^{7,23}$ The present authors reported a room-temperature non-aqueous $\mathrm{Mg} / \mathrm{O}_{2}$ battery with an electrolyte based on a modified Grignard reagent. ${ }^{24}$ This electrolyte was previously shown to allow for efficient $\mathrm{Mg}$ deposition/dissolution, and exhibited high oxidative stability, ${ }^{25}$ but the reversible energy density exhibited by $\mathrm{Mg} / \mathrm{O}_{2}$ cells based on it was low. ${ }^{21-22,24}$

It is well-known that Grignard reagents react vigorously with water and are pyrophoric. ${ }^{26}$ Consequently, the development of less reactive electrolytes is an area of active research. One promising option is the all-inorganic magnesium aluminum chloride complex (MACC) reported by Doe et al. ${ }^{27}$ MACC is synthesized by reacting a simple $\mathrm{Mg}$ salt with a Lewis acid in a non-aqueous solvent such as dimethoxyethane (DME) or tetrahydrofuran (THF). Electrochemical conditioning of the initially synthesized solution activates the electrochemical species responsible for reversible $\mathrm{Mg}$ deposition. ${ }^{28-}$

${ }^{30}$ Conditioned MACC/DME allows Mg plating and stripping at room temperature with low deposition overpotentials $(<300 \mathrm{mV}$ vs. $\mathrm{Mg} / \mathrm{Mg}^{2+/ 0}$ ), high coulombic efficiency (>95\%), and high oxidative stability ( $>3 \mathrm{~V}$ vs. $\mathrm{Mg}^{2+/ 0}$ with a Pt working electrode). In addition, the conductivity of MACC is relatively high $(\sim 2 \mathrm{mS} / \mathrm{cm})^{27}$ when compared to Grignard electrolytes $(\sim 0.3 \mathrm{mS} / \mathrm{cm}) .{ }^{31}$ Although the exceptional properties exhibited by MACC suggest its promise for use in metal-air batteries, to our knowledge no reports of $\mathrm{Mg} / \mathrm{O}_{2}$ cells based on MACC/DME exist.

A high-capacity $\mathrm{Mg} / \mathrm{O}_{2}$ battery based on MACC/DME is reported here. This room-temperature $\mathrm{Mg} / \mathrm{O}_{2}$ cell exhibits a capacity similar to those of elevated-temperature cells based on simple $\mathrm{Mg}$ salt electrolytes, ${ }^{21-22}$ yet is much higher than that of the room- 
temperature $\mathrm{Mg} / \mathrm{O}_{2}$ battery based on a modified Grignard electrolyte. ${ }^{24}$ The discharge product of the MACC/DME $\mathrm{Mg} / \mathrm{O}_{2}$ cell is found to be a mixture of $\mathrm{Mg}\left(\mathrm{ClO}_{4}\right)_{2}$ and $\mathrm{MgCl}_{2}$, which arises from slow decomposition of metastable $\mathrm{Mg}\left(\mathrm{ClO}_{4}\right)_{2}$ into $\mathrm{MgCl}_{2}$. The presence of $\mathrm{Cl}$ points to undesirable electrolyte consumption during discharge-product formation.

In agreement with earlier studies using different electrolytes, ${ }^{21-22}$ the rechargeability of the $\mathrm{Mg} / \mathrm{O}_{2}-\mathrm{MACC} / \mathrm{DME}$ battery was found to be poor. This observation prompted additional characterization using electrochemical impedance spectroscopy (EIS) to identify factors that block reversal of the cell reaction. EIS shows that exposure to an $\mathrm{O}_{2}$-saturated electrolyte accelerates film formation on $\mathrm{Mg}$ metal, leading to an impedance increase. In a $\mathrm{Mg} / \mathrm{O}_{2}$ cell, such an effect would arise from $\mathrm{O}_{2}$ crossover to the negative electrode from the positive. In addition, EIS reveals a film resistance on the positive electrode that rises in correlation with depth of discharge, suggesting that the growth of an electrically insulating discharge product impedes cell performance. Ironically, the vastly larger quantity of discharge product produced in cells using MACC/DME (and associated electrode passivation) could explain the limited recharge capacity in comparison to cells based on the modified Grignard electrolyte.

The effects of discharge rate on capacity and discharge voltage were examined from 0.02 to $1 \mathrm{mAcm}^{-2}$ (superficial). The results suggest that slow diffusion of $\mathrm{O}_{2}$ in the electrolyte also contributes to limitations in discharge capacity.

We conclude that efforts to improve the performance of nonaqueous $\mathrm{Mg} / \mathrm{O}_{2}$ cells should aim to (i.) minimize $\mathrm{O}_{2}$ crossover, (ii.) bypass or improve charge transfer through the discharge product, and (iii.) identify cathode/electrolyte combinations that are highly permeable to $\mathrm{O}_{2}$.

\section{METHODS}

Experimental. $\mathrm{Mg} / \mathrm{O}_{2}$ cycling experiments were performed using cells designed for metal/ $\mathrm{O}_{2}$ testing, depicted in the Supporting Information (SI) Fig. S1. Cell fabrication and disassembly closely followed the procedures described earlier by Griffith et al. ${ }^{32} \mathrm{Mg} / \mathrm{O}_{2}$ cells (EL-CELL Gmbh, Germany) were assembled by sandwiching a glass-fiber separator ( $0.5 \mathrm{~mm}$ thick, EL-CELL Gmbh, Germany) between a planar metallic-Mg negative electrode (99.9\%, Goodfellow, USA) and a porous-carbon positive electrode $(26 \mathrm{mg}$, SIGRACET GDL 24 BC, Ion Power, Inc., USA). A stainless-steel plate with $1.5 \mathrm{~mm}$ diameter perforations (EL-CELL Gmbh, Germany) acted as a positive current collector, and was coated with evaporatively deposited $\mathrm{Pt}$ to impede corrosion during testing. The perforations in the plate allowed contact between the carbon and stagnant $\mathrm{O}_{2}$ (99.993\%, Cryogenic Gases, USA; 2 bar absolute). The separator and carbon were saturated with an electrolyte comprising $\mathrm{MgCl}_{2}$ (99.99\%, Sigma-Aldrich, USA) and $\mathrm{AlCl}_{3}$ (99.999\%, SigmaAldrich, USA) in DME (99.5\%, anhydrous, Sigma-Aldrich, USA), referred to above as MACC/DME. The electrolyte was produced using the precursor materials and conditioned to achieve high performance ( $c f$. Fig. S2, S3, S4) via batch electrolysis (i.e., holding at a negative potential $500 \mathrm{mV}$ below the $\mathrm{Mg}$ deposition overpotential until cyclic voltammetry showed the coulombic efficiency for $\mathrm{Mg}$ plating/stripping to be $>96 \%$ ). Discharge experiments were performed at room temperature using a series 4000 battery tester (Maccor, USA). To probe the discharge mechanism, the discharge product was characterized by scanning electron microscopy
(SEM), energy dispersive x-ray spectroscopy (EDS), x-ray diffraction (XRD), Raman spectroscopy (RS), Auger electron spectroscopy (AES), and x-ray photoelectron spectroscopy (XPS). Additional details are provided in the SI.

Computational. Density functional theory calculations (VASP code $)^{33-35}$ were used to characterize the electronic structures of $\mathrm{Mg}\left(\mathrm{ClO}_{4}\right)_{2}$ and $\mathrm{MgCl}_{2}$ and to estimate the enthalpy and freeenergy changes associated with the decomposition reaction hypothesized to accompany discharge (described below). Blochl's projector augmented wave (PAW) method $^{36}$ was used to treat the core/valence electron interaction. The generalized gradient approximation (GGA) expressed with the formulation of PerdewBurke-Ernzerhof $(\mathrm{PBE})^{37}$ was used for the exchange-correlation energy. Additional calculations were preformed using van der Waals-aware functionals. ${ }^{38-40}$ The Brillouin zone was sampled with a $\Gamma$-centered $k$-point mesh with density $12 \times 12 \times 6$ for $\mathrm{Mg}\left(\mathrm{ClO}_{4}\right)_{2}$ and $12 \times 3 \times 12$ for $\mathrm{MgCl}_{2}$. Lattice constants were determined by relaxing the cell shape, volume, and atom positions. A plane-wave cutoff energy of $520 \mathrm{eV}$ and a force tolerance of $0.04 \mathrm{eV} / \AA$ was used for all geometry optimizations. The ground state energy of the $\mathrm{O}_{2}$ molecule was evaluated using spin-polarized calculations.

\section{RESULTS AND DISCUSSION}

Electrochemical Testing. Figure 1 shows representative discharge curves for the MACC/DME-based $\mathrm{Mg} / \mathrm{O}_{2}$ cell at six discharge rates ranging from 0.02 to $1 \mathrm{~mA} \mathrm{~cm}$ (superficial). The open-circuit $(\mathrm{OC})$ voltage prior to discharge $(2.0 \pm 0.1 \mathrm{~V})$ is similar

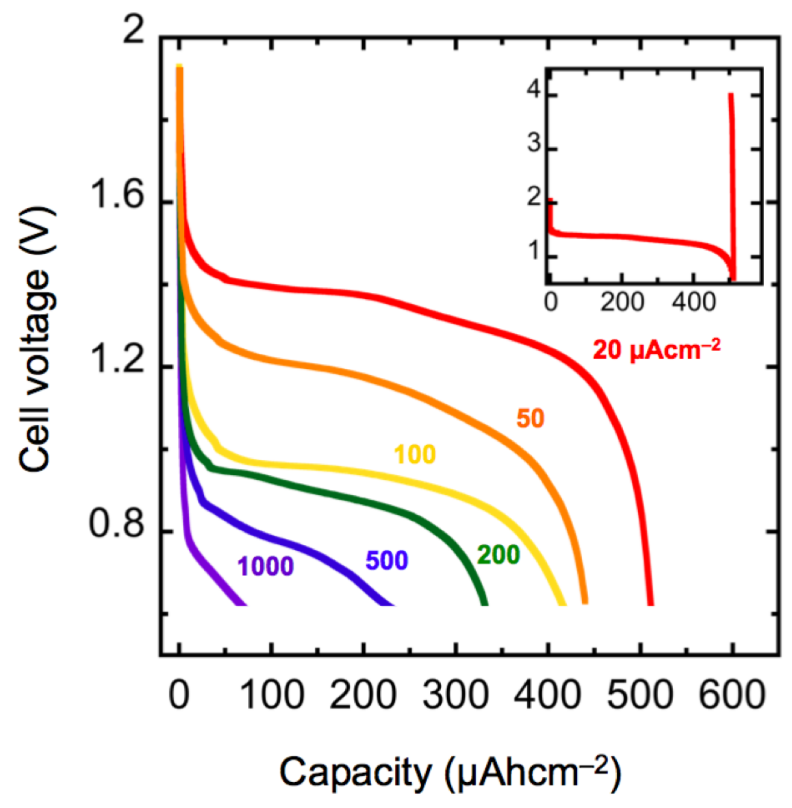

Figure 1. Cell voltage vs. capacity for $\mathrm{Mg} / \mathrm{O}_{2}$ cells at current densities ranging from 0.02 to $1 \mathrm{~mA} \mathrm{~cm}{ }^{-2}$ (superficial). The inset shows a typical discharge/charge cycle at $0.02 \mathrm{~mA} \mathrm{~cm}^{-2}$.

to the voltage reported previously for other non-aqueous $\mathrm{Mg} / \mathrm{O}_{2}$ cells. ${ }^{21,24}$ In an earlier report the authors argued that an OC voltage of $\sim 2.0 \mathrm{~V}$ results from the half-reaction associated with superoxide formation at the positive electrode, since $\mathrm{O}_{2}{ }^{-}$forms from $\mathrm{O}_{2}$ at $\sim 2 \mathrm{~V}$ vs $\mathrm{Mg} / \mathrm{Mg}^{2+} \cdot{ }^{24}$ Control experiments in which the cells were not exposed to $\mathrm{O}_{2}$ showed negligible capacity (Fig. S5), suggesting that the presence of $\mathrm{O}_{2}$ is necessary for discharge to occur. 
The cell based on MACC/DME exhibits a capacity of $\sim 400 \mu \mathrm{Ah}$ $\mathrm{cm}^{-2}$ at a discharge rate of $0.05 \mathrm{mAcm}^{-2}$. (This corresponds to a specific capacity of $\sim 38 \mathrm{mAhg}_{\text {cathode }^{-1}}$.) In contrast, the electrochemical capacities reported prvioiusly for a similar $\mathrm{Mg} / \mathrm{O}_{2}$ cell using the 4:1 ( $\left.\mathrm{PhMgCl})_{4}-\mathrm{Al}(\mathrm{OPh})_{3} / \mathrm{THF}\right)$ modified Grignard electrolyte was much lower, $\sim 13 \mu \mathrm{Ah} \mathrm{cm}^{-2}$, at one-tenth the discharge rate $\left(0.005 \mathrm{~mA} \mathrm{~cm}^{-2}\right) .^{24}$

The large difference in capacity between cells based on Grignard/THF and MACC/DME owes at least partially to the higher conductivity of the MACC solution and the higher solubility of $\mathrm{O}_{2}$ in DME. Indeed, $\mathrm{O}_{2}$ permeability (defined as the product of saturated $\mathrm{O}_{2}$ concentration and effective diffusivity) is thought to contribute to capacity limitations in $\mathrm{Li} / \mathrm{O}_{2}$ batteries. ${ }^{32,41}$ The conductivity of the modified Grignard electrolyte examined previously was reported to be $1.24 \mathrm{mScm}^{-1},{ }^{25}$ whereas the conductivity of the conditioned MACC/DME was $2.21 \mathrm{mScm}^{-1}$. The latter value agrees with the $\sim 2 \mathrm{mScm}^{-1}$ reported by Doe et al. ${ }^{27}$ Furthermore, the solubility of $\mathrm{O}_{2}$ in DME has been reported to be 5 times higher than in THF. $^{42-43}$ Taken together, these data support the notion that differences in oxygen permeability between the electrolytes can be associated with the observed differences in capacity. Additional tuning of the electrolyte composition could raise the capacities observed for $\mathrm{Mg} / \mathrm{O}_{2}$ systems. For example, varying the donor number of the solvent appears to have a significant effect on the capacity of nonaqueous $\mathrm{Li} / \mathrm{O}_{2}$ cells. $^{44}$

Recharging at $0.02 \mathrm{mAcm}^{-2}$ yielded negligible recharge capacity before the cutoff voltage of $4 \mathrm{~V}$ vs. $\mathrm{Mg} / \mathrm{Mg}^{2+}$ was reached ( $c f$. Fig. 1 inset). This response of the $\mathrm{Mg} / \mathrm{O}_{2}-\mathrm{MACC} / \mathrm{DME}$ cells differs substantially from the behavior observed previously for $\mathrm{Mg} / \mathrm{O}_{2}$ Grignard/THF cells, which exhibited some rechargeability, albeit at low recharge rates $\left(0.005 \mathrm{mAcm}^{-2}\right) .{ }^{24}$ Possible explanations for this distinct behavior are discussed in conjunction with the EIS results below.

Discharge-Product Characterization. Figure 2 shows SEM images of positive (carbon) electrodes harvested from $\mathrm{Mg} / \mathrm{O}_{2}$ MACC/DME cells. Fig. 2a shows an electrode after first discharge, which is covered with discharge product only on the side closest to the $\mathrm{O}_{2}$ inlet. This product was absent from a control electrode (inset of Fig. 2b) held under oxygen at OC (i.e., galvanostatically at 0 A) for the same time period. Higher-magnification images in Fig. $2 \mathrm{~b}$ reveal that the product comprises faceted particles. The much higher capacity of $\mathrm{MgO}_{2}-\mathrm{MACC} / \mathrm{DME}$ cells compared to $\mathrm{MgO}_{2}$ Grignard cells is reflected by the much larger amount of discharge product visible on the electrode following discharge. Fig. S10 compares SEM images of carbon electrodes that were imaged after discharge using MACC/DME and the modified Grignard electrolyte. The electrode from the MACC/DME cell exhibits high surface coverage by the product, which extends beyond the boundaries of the perforations in the current collector (these perforations allow direct contact between $\mathrm{C}$ and $\mathrm{O}_{2}$ ); in contrast, the electrode from the modified Grignard-based cell exhibits a single incomplete layer of product only on the portion of the carbon surface that was in contact with $\mathrm{O}_{2}$.

The discharge-product composition was characterized using $\mathrm{x}$ ray diffraction (XRD), energy dispersive spectroscopy (EDS), Auger electron spectroscopy (AES), and x-ray photoelectron spectroscopy (XPS). Figure 3a shows XRD patterns collected from the positive electrode at the end of a discharge at $0.05 \mathrm{mAcm}^{-2}$, and for a control electrode held at OC for the same period. At the end of discharge, peaks associated with $\mathrm{MgCl}_{2}$ and $\mathrm{Mg}\left(\mathrm{ClO}_{4}\right)_{2}$ are clearly present in the diffraction pattern from the positive electrode.

Figure $3 \mathrm{~b}$ presents EDS spectra collected from two different spots on the discharge-product layer. The EDS data qualitatively confirms that the discharge product is rich in $\mathrm{Cl}$, and indicates some degree of spatial nonuniformity. RS, AES and XPS (Fig S11, S12) also confirm the spatial nonuniformity. RS shows that peaks for $\mathrm{MgCl}_{2}$ and $\mathrm{Mg}\left(\mathrm{ClO}_{4}\right)_{2}$ can be observed in different locations on parts of the electrode surface covered by discharge product. Similarly, Mg KL $L_{2,3} L_{2,3}$ AES spectra and Mg 2p XPS spectra collected from different spots on the discharge product show that the bind-
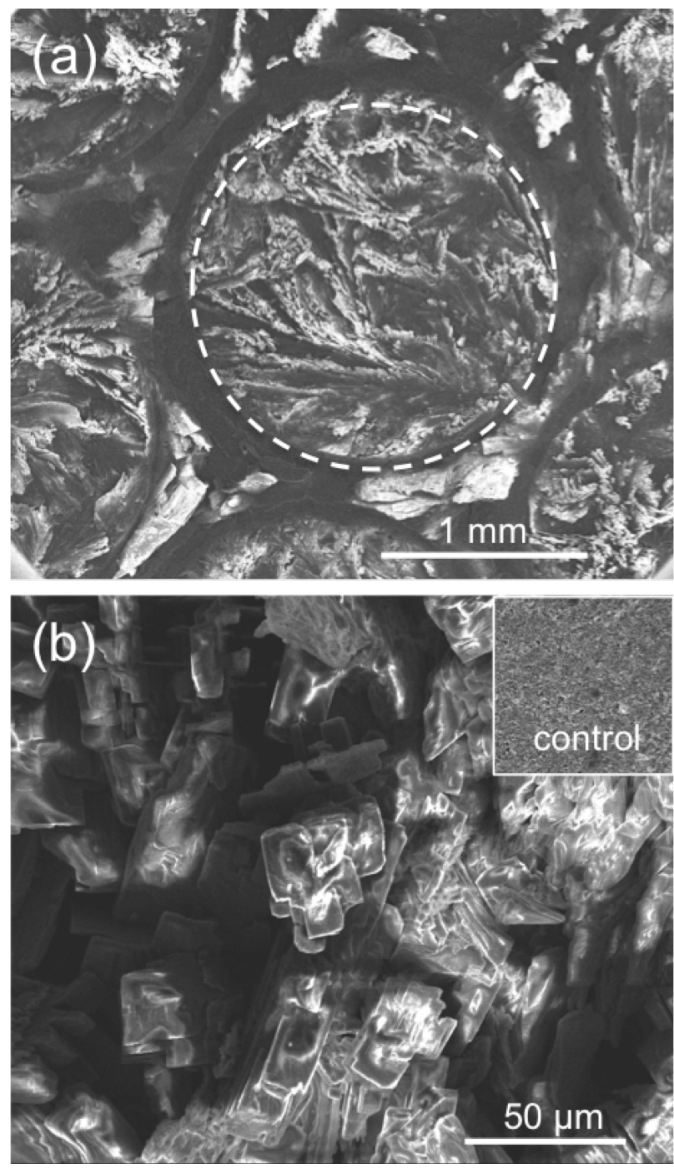

Figure 2. (a) SEM image of the positive-electrode surface on the side closest to the $\mathrm{O}_{2}$ gas inlet after first discharge $\left(0.05 \mathrm{mAcm}^{-2}\right)$. The dashed circle represents the boundary of the region that was directly exposed to $\mathrm{O}_{2}$ through perforations in the Pt-coated current collector. (b) Higher magnification of the electrode after first discharge, with an inset image of a control electrode exposed to $\mathrm{O}_{2}$ in a similar cell held at open circuit for the same period.

ing energies vary with respect to location. Taken together, these data suggest that the discharge product comprises a mixture of $\mathrm{Mg}\left(\mathrm{ClO}_{4}\right)_{2}$ and $\mathrm{MgCl}_{2}$. Anhydrous $\mathrm{Mg}\left(\mathrm{ClO}_{4}\right)_{2}$ is believed to decompose spontaneously into $\mathrm{MgCl}_{2}$ and $\mathrm{O}_{2}$ at room temperature via the reaction: ${ }^{45}$

$$
\mathrm{Mg}\left(\mathrm{ClO}_{4}\right)_{2} \rightarrow \mathrm{MgCl}_{2}+4 \mathrm{O}_{2} \text {. }
$$

Thus the nonuniform product observed could be explained by electrochemical $\mathrm{Mg}\left(\mathrm{ClO}_{4}\right)_{2}$ formation, which is followed by gradual chemical decomposition into $\mathrm{MgCl}_{2}$ and $\mathrm{O}_{2}$. 

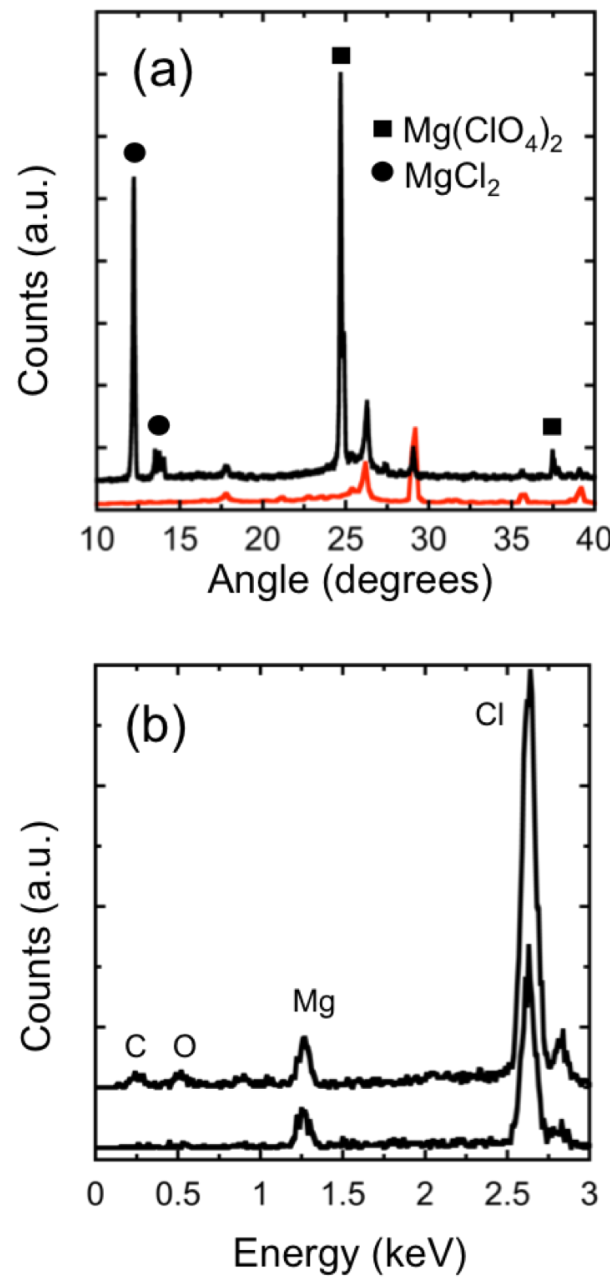

Figure 3. (a) XRD patterns of a discharged cathode (black) and a control cathode (red). Unlabeled peaks correspond to the carbon positive electrode. (b) EDS spectra collected in spot mode from two locations on the discharge product.

DFT Calculations. Density functional theory calculations were preformed to evaluate the energetics of $\mathrm{Mg}\left(\mathrm{ClO}_{4}\right)_{2}$ decomposition via Eq. 1. The calculated enthalpy and free energy of reaction are $\Delta \mathrm{H}_{\mathrm{r}}=-42.6 \mathrm{~kJ} / \mathrm{mol}$ and $\Delta \mathrm{G}_{\mathrm{r}}=-285.7 \mathrm{~kJ} / \mathrm{mol}$, respectively, indi- cating that the decomposition of magnesium perchlorate into magnesium chloride should be spontaneous. Additional details regarding the DFT calculations can be found in the SI, Tables S1 and S2.

The discharge-product composition in $\mathrm{Mg} / \mathrm{O}_{2}-\mathrm{MACC} / \mathrm{DME}$ cells differs from the mixed $\mathrm{MgO} / \mathrm{MgO}_{2}$ product previously observed in cells based on a modified Grignard electrolyte. ${ }^{24}$ Nevertheless, the formation of $\mathrm{Cl}-\mathrm{O}$ complexes has been observed in aqueous $\mathrm{Mg}$ /air chemistries using $\mathrm{NaCl}$ electrolytes. ${ }^{46}$ Computational studies suggest that conditioned MACC/DME electrolyte contains chloromagnesium cations such as $\mathrm{MgCl}^{+}$and $\mathrm{Mg}_{2} \mathrm{Cl}_{3}{ }^{+} .{ }^{47} \mathrm{In}$ principle, these species could react chemically with electrochemically formed $\mathrm{O}_{2}^{-}$to produce $\mathrm{Mg}\left(\mathrm{ClO}_{4}\right)_{2}$. Such a reaction would be consistent with the observed discharge voltages shown in Fig 1. Both $\mathrm{Mg}\left(\mathrm{ClO}_{4}\right)_{2}$ and $\mathrm{MgCl}_{2}$ are expected to be insulators, so sluggish electron transport through them could limit rechargeability. ${ }^{48}$

49 Indeed, GGA-DFT calculations confirm that $\mathrm{MgCl}_{2}$ and $\mathrm{Mg}\left(\mathrm{ClO}_{4}\right)_{2}$ are both insulators with large bandgaps of $5.6 \mathrm{eV}$ and $5.3 \mathrm{eV}$, respectively. (Since semi-local functionals such as the GGA tend to underestimate bandgaps, these calculations probably represent lower bounds to the true bandgaps. Fig. S13 shows the density of states for each compound.)

The presence of $\mathrm{Cl}$ in the discharge product indicates that electrolyte is consumed during or immediately after the electrochemical discharge reaction step. Most $\mathrm{Mg}$-halogen compounds have Gibbs free energies of formation similar to, or more negative than, that of $\mathrm{MgO}\left(\mathrm{MgCl}_{2}:-592 \mathrm{kJmol}^{-1}, \mathrm{MgF}_{2}:-1071 \mathrm{kJmol}^{-1}, \mathrm{MgBr}_{2}\right.$ : $\left.504 \mathrm{kJmol}^{-1}, \mathrm{MgO}:-568 \mathrm{kJmol}^{-1}\right){ }^{50}$ Thus it is likely that $\mathrm{Cl}, \mathrm{F}$, or Br in the electrolyte could be incorporated into the discharge product of a $\mathrm{Mg} / \mathrm{O}_{2}$ battery. For future studies, it is recommended that halogen-free electrolytes be explored.

Electrochemical Impedance Spectroscopy. The evolution of internal resistance was studied using EIS to explore the limited rechargeability of MACC/DME cells. Figure 4(a) shows Nyquist plots for a symmetric $\mathrm{Mg} / \mathrm{Mg}$ cell with a $0.5 \mathrm{~mm}$ thick glass-fiber separator soaked with MACC/DME electrolyte and operated under Ar. The cell was kept at OC for a total of 3 hours, during which an impedance spectrum was gathered every 10 minutes to examine temporal changes in the resistance of the $\mathrm{Mg}$ /electrolyte interface. The first EIS measurement (corresponding to time $=0 \mathrm{~min}$ ) was recorded less than 5 minutes after the cell was assembled.
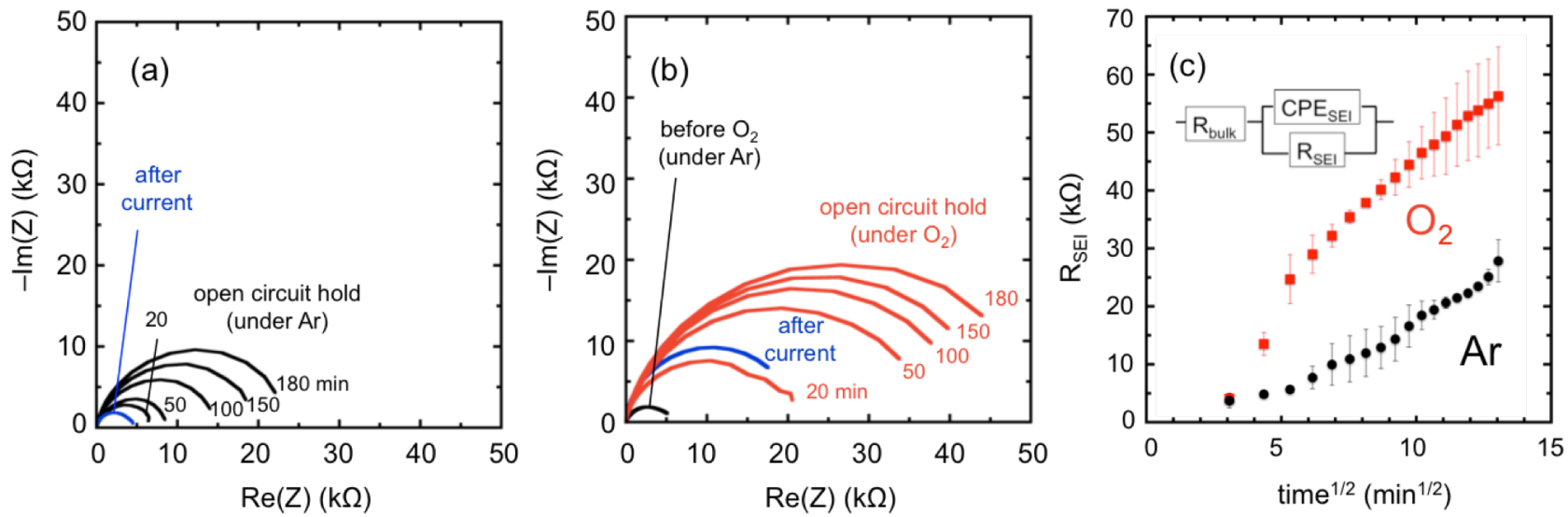

Figure 4. (a) Nyquist plots for a $\mathrm{Mg} / \mathrm{Mg}$ cell containing MACC/DME electrolyte under Ar at various times during an OC hold (black) and after passing $0.075 \mathrm{mAh} \mathrm{cm}^{-2}$ through the cell at $0.05 \mathrm{~mA} \mathrm{~cm} \mathrm{~cm}^{-2}$ (blue). (b) Nyquist plots for a $\mathrm{Mg} / \mathrm{Mg}$ cell using $\mathrm{MACC} / \mathrm{DME}$ before $\mathrm{O}_{2}$ exposure (black), under $\mathrm{O}_{2}$ at various times after $\mathrm{O}_{2}$ exposure during an $\mathrm{OC}$ hold (red), and after passing $0.075 \mathrm{mAh} \mathrm{cm}^{-2}$ (blue). (c) Equivalent-circuitmodel fit for $\mathrm{R}_{\text {SEI }}$ during $\mathrm{OC}$ holds for $\mathrm{Mg} / \mathrm{Mg}$ cells under $\mathrm{Ar}$ (black circles) and under $\mathrm{O}_{2}$ (red squares). 
A Nyquist plot produced from the $\mathrm{Mg} / \mathrm{Mg}$ cell under $\mathrm{Ar}$ shows a single depressed semi-circle. Depressed semicircles are often observed in battery impedance studies and are commonly attributed to electrode surface roughness. ${ }^{51}$ The radius of the semi-circle grows as a function of time, indicating an impedance increase arising from the formation of a partially passivating phase on the electrode surfaces. This behavior is similar to that observed for solidelectrolyte interphase (SEI) formation in Li-ion battery negative electrodes. After the $3 \mathrm{~h} \mathrm{OC} \mathrm{hold,} 0.075 \mathrm{mAh} \mathrm{cm}^{-2}$ of charge (a 1.5 hour discharge at $0.05 \mathrm{~mA} \mathrm{~cm}{ }^{-2}$ ) was passed through the cell and another impedance spectrum was recorded (shown as the blue curve in Fig. 3a). The interfacial impedance decreased substantially after current was applied, suggesting electrochemically-driven dissolution of an SEI-like layer from the Mg electrode surfaces.

Contributions to the impedance associated with dissolved $\mathrm{O}_{2}$ in the electrolyte were probed using a symmetric $\mathrm{Mg} / \mathrm{Mg}$ cell exposed to $\mathrm{O}_{2}$, rather than Ar, during the $\mathrm{OC}$ hold, for which Nyquist plots are shown in Fig. 4b. The black curve represents an impedance spectrum collected before $\mathrm{O}_{2}$ exposure, which is similar to the data in Fig. 4a. In contrast to the Ar-only cell, the impedance of the cell exposed to $\mathrm{O}_{2}$ is larger, and grows more rapidly. The subsequent passage of $0.075 \mathrm{mAh} \mathrm{cm}^{-2}$ at $0.05 \mathrm{~mA} \mathrm{~cm}^{-2}$ results in an impedance decrease, but the cell does not return to its state before $\mathrm{O}_{2}$ exposure.

To quantify the effects of $\mathrm{O}_{2}$ exposure, an equivalent-circuit model (ECM), illustrated on Fig. 4c, was used to fit the EIS data gathered from both the Ar- and $\mathrm{O}_{2}$-exposed $\mathrm{Mg} / \mathrm{Mg}$ cells. In the $\mathrm{ECM}, \mathrm{R}_{\text {bulk }}, \mathrm{R}_{\mathrm{SEI}}$, and CPE $\mathrm{E}_{\mathrm{SEI}}$ represent the bulk resistance associated with the electrolyte, and the Mg electrode's interfacial resistance and equivalent capacitance, respectively. (A more complex ECM was also considered, which included uncompensated resistance and cell capacitance elements. This was found to increase the variances in the parameters without improving goodness-of-fit; additional details can be found in the SI.)

Figure $4 \mathrm{c}$ shows how $\mathrm{R}_{\text {SEI }}$ varies with respect to the square root of time for $\mathrm{Mg} / \mathrm{Mg}-\mathrm{MACC} / \mathrm{DME}$ cells under $\mathrm{Ar}$ and $\mathrm{O}_{2}$. An increase in $\mathrm{R}_{S E I}$ is expected to correlate with the growth of an SEI-like film. Notably, $\mathrm{R}_{S E I}$ increases with time under both $\mathrm{Ar}$ and $\mathrm{O}_{2}$ atmospheres. Nevertheless, the cell exposed to $\mathrm{O}_{2}$ exhibits a more rapid rate of increase, and higher overall interfacial resistance, possibly due to oxidation of the $\mathrm{Mg}$ surface caused by the presence of $\mathrm{O}_{2}$. Interestingly, $\mathrm{R}_{\mathrm{SEI}}$ increases approximately linearly with the square root of time in both cases, suggesting a diffusion-limited filmgrowth process (Figure S7).

The evolution of $\mathrm{R}_{\text {bulk, }}$ which is associated with the resistance of the electrolyte, and given by the high-frequency intercept of the Nyquist curve with the real axis, was investigated to gain insight into the relative stability of MACC and Grignard electrolytes under $\mathrm{O}_{2}$. Comparison experiments, similar to those shown in Fig. $4 \mathrm{~b}$, were performed on a $\mathrm{Mg} / \mathrm{Mg}$ cell using the modified Grignard electrolyte. ${ }^{24-25}$ As shown in Fig S8, the rate of increase and the absolute value of $\mathrm{R}_{\text {bulk }}$ were larger for the modified Grignard electrolyte than for MACC/DME. Lower $\mathrm{R}_{\text {bulk }}$ values for MACC/DME confirm the earlier mentioned higher conductivity of MACC/DME. Furthermore, the lower rate of increase for $\mathrm{R}_{\text {bulk }}$ suggests that MACC/DME is more stable with respect to $\mathrm{O}_{2}$ exposure than the Grignard electrolyte.

In addition to stability against chemical attack by $\mathrm{O}_{2}$, the possible presence of $\mathrm{O}_{2}{ }^{-}$ions formed during cell discharge creates a strong oxidizing environment, which might be expected to further decompose electrolytes. ${ }^{52-54}$ Stability in the specific presence of $\mathrm{O}_{2}$ and its electrochemical products appears to be just as important as electrochemical stability against oxidation by the positive electrode - or even more important. These effects are illustrated by the full $\mathrm{Mg} / \mathrm{O}_{2}$ cell EIS data shown in Figure 5. During an initial OC hold under $\mathrm{Ar}$, the Nyquist plot resembles that of the symmetric $\mathrm{Mg} / \mathrm{Mg}$ cells (Fig. 4a): there is only one apparent depressed semicircle. Similar to the symmetric $\mathrm{Mg} / \mathrm{Mg}$ cells, exposure to $\mathrm{O}_{2}$ results in an impedance increase. This could be attributed to SEI-like film formation on the $\mathrm{Mg}$ surface due to $\mathrm{O}_{2}$ crossover from the positive electrode. The ECM depicted in Figure $4 \mathrm{c}$ was sufficient to model the impedance behavior of the $\mathrm{Mg} / \mathrm{O}_{2}$ cells up to this point (i.e., under OC conditions).

Upon discharge of the full $\mathrm{Mg} / \mathrm{O}_{2}$ cell (Fig. 5, blue and light blue curves), a second depressed semicircle in the Nyquist plot appeared, presumably due to the formation of a new resistive interface in the cell. This likely owes to the formation of the dischargeproduct layer. Similar EIS data (showing a new semicircle after discharge) have been observed previously during discharge of $\mathrm{Li} / \mathrm{O}_{2}$ cells. ${ }^{55}$

An augmented ECM (Fig. 5, top) containing an additional circuit element (parallel $\mathrm{CPE}_{\text {prod, }} \mathrm{R}_{\text {prod }}$ ) was used to model EIS data during and after discharge. Here, $\mathrm{CPE}_{\text {prod }}$ and $\mathrm{R}_{\text {prod }}$ represent the equivalent capacitance and resistance associated with the discharge-product layer. This layer's characteristic frequency is 4.40 $\mathrm{MHz}$, with equivalent capacitance on the order of $1 \mathrm{pF}$. Both of

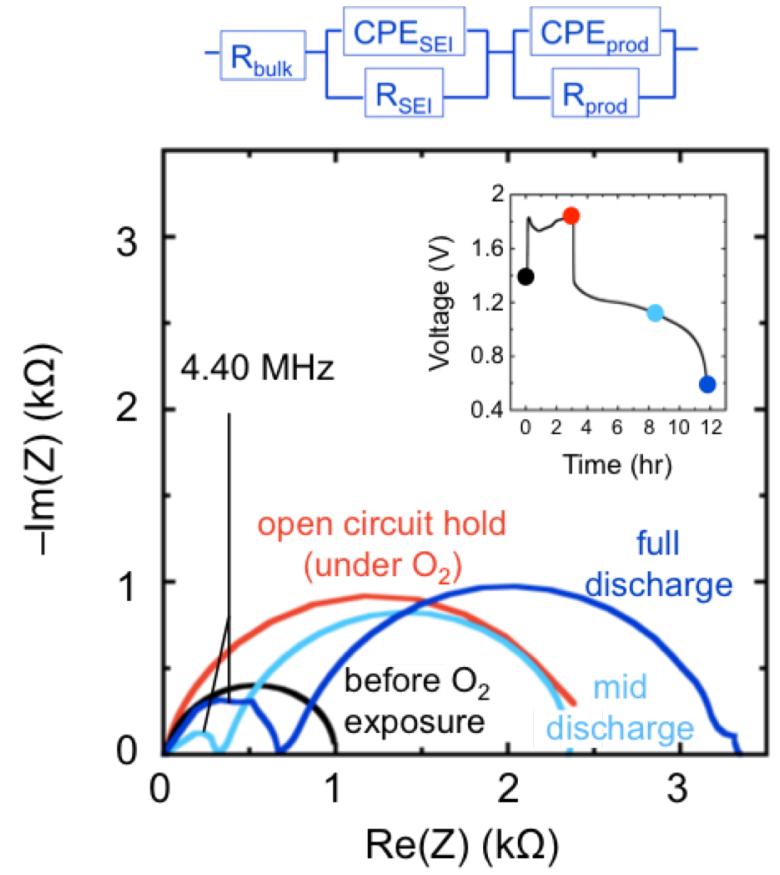

Figure 5. Electrochemical impedance spectra for a $\mathrm{Mg} / \mathrm{O}_{2}$ cell using MACC/DME electrolyte before $\mathrm{O}_{2}$ exposure (black), after OC hold under $\mathrm{O}_{2}$ (red), mid-discharge (light blue), and after discharge (blue). The inset indicates the stage of (pre-)discharge at which the EIS data was measured. The ECM used to model the spectra is shown above.

these features point to the presence of a solid/liquid interphase. ${ }^{56}$ Figure 5 also highlights that the size of the new semicircle (which scales as $\mathrm{R}_{\text {prod }}$ ) correlates with the depth of discharge. In contrast, 

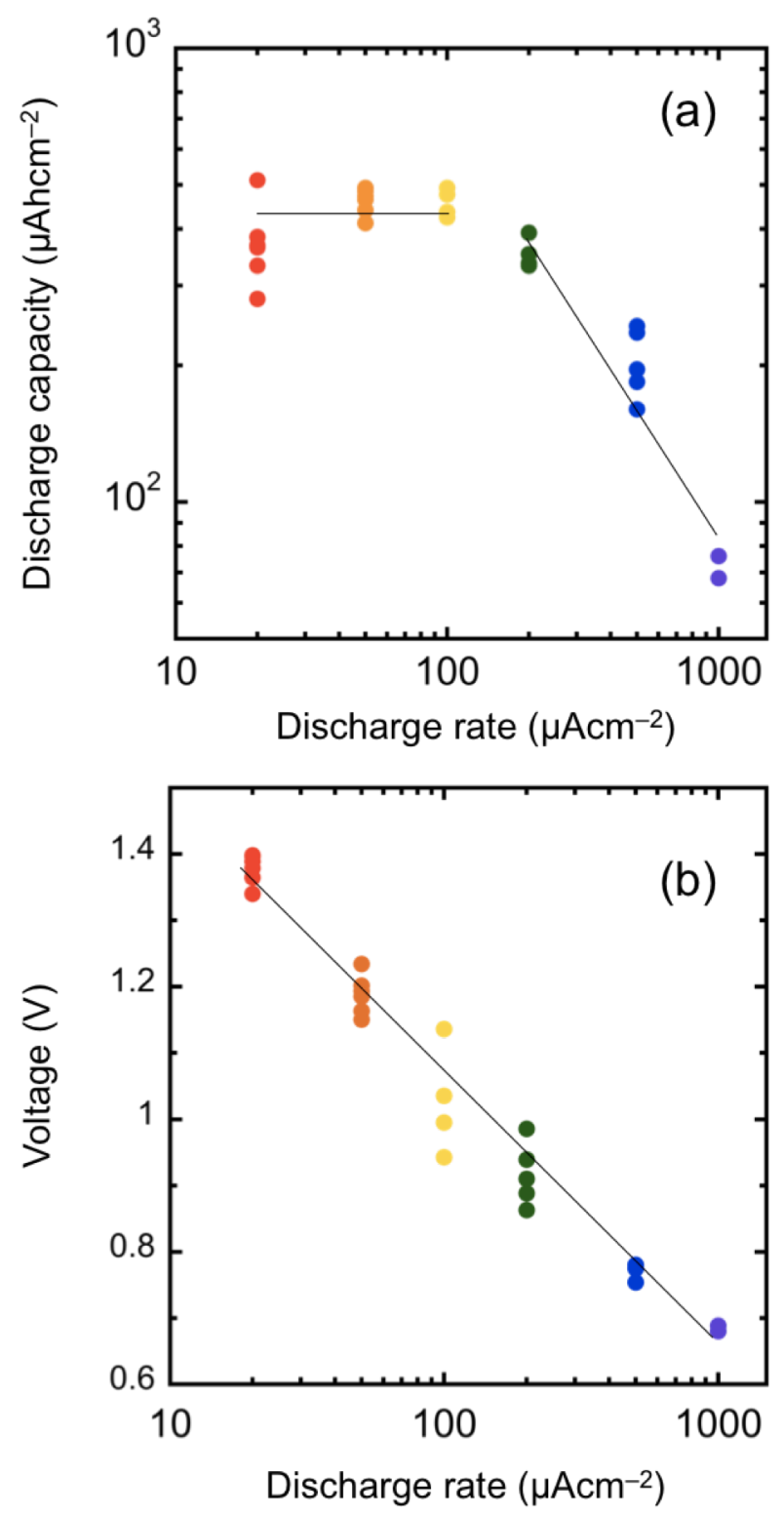

Figure 6. (a) Capacity per geometric electrode achieved at the $0.6 \mathrm{~V}$ cutoff potential as a function of discharge rate. Capacity falls as a power law with respect to discharge rate at rates higher than 0.02 $\mathrm{mAh} \mathrm{cm}{ }^{-2}$. (b) Cell voltage at $50 \%$ depth-of-discharge as a function of discharge rate.

the EIS data from $\mathrm{Mg} / \mathrm{O}_{2}$ cells using the modified Grignard electrolyte do not show the formation of a new semicircle upon discharge (see Fig. S9). The absence of this feature - which was previously ascribed to the formation of a resistive discharge product - provides insight regarding the greater rechargeability noted for the Grignard electrolyte. In that system a mixed discharge product comprising $\mathrm{MgO}$ and $\mathrm{MgO}_{2}$ was observed. ${ }^{24}$ Both of these compounds were predicted to be insulators, similar to the $\mathrm{MgCl}_{2}$ and $\mathrm{Mg}\left(\mathrm{ClO}_{4}\right)_{2}$ products found in the discharged MACC/DME cell. ${ }^{57}$ Nevertheless, the discharge product in the Grignard-based cell covered only a fraction of the electrode surface. This behavior differs from the much higher coverages shown in Fig. 2. Hence, the larger quantity of (insulating) discharge product present in the MACC/DME cell likely contributes to a higher product-film resistance, leading to limited rechargeability relative to the Grignardbased cell.
In summary, EIS measurements on symmetric $\mathrm{Mg} / \mathrm{Mg}$ cells indicate that SEI-like film formation contributes to impedance at the $\mathrm{Mg} /$ electrolyte interface; moreover, the presence of $\mathrm{O}_{2}$ accelerates the formation of these films. The EIS for full $\mathrm{Mg} / \mathrm{O}_{2}$ cells shows that growth of the discharge-product introduces a new and sizable interfacial resistance. The additional impedance contribution associated with the formation of a new interphase, arising from the low electrical conductivity of the discharge product and its high coverage on the electrode, likely explains the poor rechargeability of $\mathrm{Mg} / \mathrm{O}_{2}$ cells using MACC/DME.

Rate Dependence. In addition to energy density and rechargeability, rate capability is another important performance metric for batteries. The MACC/DME electrolyte allowed $\mathrm{Mg} / \mathrm{O}_{2}$ cells to be discharged at a wide range of current densities, ranging from 0.02 to $1 \mathrm{~mA} \mathrm{~cm}{ }^{-2}$. These compare to rates at which $\mathrm{Li} / \mathrm{O}_{2}$ cells have been tested, offering the possibility for a direct comparison of $\mathrm{Li}$ and $\mathrm{Mg}$ chemistries.

Figure 6 shows discharge capacity and cell voltage at 50\% depthof-discharge as a function of discharge rate from 28 independently fabricated $\mathrm{Mg} / \mathrm{O}_{2}$ cells. The data shows (Fig. 6a) that discharge rate does not significantly affect capacity at rates below $0.01 \mathrm{~mA}$ $\mathrm{cm}^{-2}$. However, capacity decreases dramatically with increasing discharge rate at rates above $0.02 \mathrm{~mA} \mathrm{~cm}^{-2}$.

The higher-rate data were analyzed using Peukert's law, which is an empirical relation linking discharge capacity, $q_{\text {total, }}$ and the discharge current density, $i:^{58}$

$$
\ln \left(\frac{q_{\text {total }}}{q_{\text {ref }}}\right)=(1-k) \ln \left(\frac{i}{i_{\text {ref }}}\right)
$$

Here $k$ is the Peukert coefficient, $i_{\text {ref }}$ is a reference current density (in this case, $1 \mathrm{~mA} \mathrm{~cm}^{-2}$ ), and $q_{\text {ref }}$ is the capacity at $i_{\text {ref. }}$ The Peukert exponent, $k$, describes the ability of a battery to retain its capacity with increasing rate, and can be compared across different battery chemistries. An ideal battery would have $k=1$, meaning that the cell capacity is unchanged as a function of discharge rate. (For reference, $k$ values for $\mathrm{Li}$-ion batteries fall within the range of $1.6 \pm$ $0.1,^{32}$ whereas those of $\mathrm{Pb} /$ acid cells are nearer $1.4 .^{59}$ ) Since drawing a current is associated with energy dissipation, $k>1$. The capacities observed above $0.02 \mathrm{~mA} \mathrm{~cm}{ }^{-2}$ for $\mathrm{Mg} / \mathrm{O}_{2}$ cells using MACC/DME follow a power-law dependence on the discharge current. The calculated Peukert exponent is 1.9, with a reference capacity of $91 \mu \mathrm{Ah} \mathrm{cm}^{-2}$ at $1 \mathrm{~mA} \mathrm{~cm}{ }^{-2}$. This $k$ value agrees well with the assumption that battery performance is limited by liquid-phase $\mathrm{O}_{2}$ diffusion, which manifests as a Peukert exponent of 2. Compared to the $\mathrm{Li} / \mathrm{O}_{2}$ chemistry, for which $k=1.6,{ }^{32} \mathrm{Mg} / \mathrm{O}_{2}$ cells appear to exhibit lower rate capability. The transition from $k=\sim 1$ (below $0.01 \mathrm{~mA} \mathrm{~cm}^{-2}$ ) to $k>1$ (above $0.02 \mathrm{~mA} \mathrm{~cm}^{-2}$ ) is commonly observed for metal $/ \mathrm{O}_{2}$ batteries. ${ }^{41,60}$

Figure 6(b) shows the cell potential at 50\% depth-of-discharge as a function of discharge rate. Following an analysis similar to that of Viswanathan et al., ${ }^{61}$ the present data reveals a Tafel slope of 4.9 $\mathrm{V}^{-1}$ and an exchange-current density of $1.6 \mu \mathrm{A} \mathrm{cm} \mathrm{cm}^{-2}$ (superficial). Compared to $\mathrm{Li} / \mathrm{O}_{2}$ cells operated at the same rates (Tafel slope 11 $\pm 1 \mathrm{~V}^{-1}$ and exchange current density $7 \pm 3 \mu \mathrm{A} \mathrm{cm}{ }^{-2}$ ), the present $\mathrm{Mg} / \mathrm{O}_{2}$ cells have a lower exchange-current density, suggesting that kinetic overpotentials are higher.

\section{CONCLUSION}


A non-aqueous $\mathrm{Mg} / \mathrm{O}_{2}$ cell based on the MACC/DME electrolyte was demonstrated and found to exhibit high discharge capacity but poor rechargeability. The discharge product was characterized using several techniques, and was determined to be a mixture of crystalline $\mathrm{Mg}\left(\mathrm{ClO}_{4}\right)_{2}$ and $\mathrm{MgCl}_{2}$. This combination is consistent with a discharge reaction that proceeds via initial reduction of $\mathrm{O}_{2}$ to $\mathrm{O}_{2}{ }^{-}$, followed by chemical formation of $\mathrm{Mg}\left(\mathrm{ClO}_{4}\right)_{2}$ and its (slow) partial decomposition into $\mathrm{MgCl}_{2}$ and $\mathrm{O}_{2}$. The presence of $\mathrm{Cl}$ in the discharge product suggests that the electrolyte participates in the discharge reaction. The MACC/DME cell yielded significantly higher capacity than a similar cell based on a modified Grignard/THF electrolyte. ${ }^{24}$ This behavior is consistent with the larger quantity of discharge product visible on the surface of the MACC/DME positive electrode, which appears to cover most of the electrode surface, and with the higher oxygen solubility and conductivity of the MACC/DME system.

The low recharge capacity of the MACC/DME system motivated an impedance study on $\mathrm{Mg} / \mathrm{Mg}$ symmetric cells and on full $\mathrm{Mg} / \mathrm{O}_{2}$ cells as a function of $\mathrm{O}_{2}$ exposure and applied current. EIS measurements showed that the formation of an SEI-like film on $\mathrm{Mg}$ electrodes is accelerated by $\mathrm{O}_{2}$ exposure. The application of current reduces the cell impedance, possibly by driving removal of the SEIlike layer. In full $\mathrm{Mg} / \mathrm{O}_{2}$ cells the formation of the discharge product layer apparently contributes substantially to cell impedance, and coincides with the appearance of a new semicircle in EIS measurements. This behavior reflects the insulating nature of the $\mathrm{Mg}\left(\mathrm{ClO}_{4}\right)_{2} / \mathrm{MgCl}_{2}$ discharge product and the relatively large amount of product formed in the MACC/DME system. In contrast, a much smaller amount of discharge product was generated in a prior study using a modified Grignard electrolyte. These differences could explain the low rechargeability of the MACC/DME cells in comparison to the Grignard-based systems. Redox mediators and cell designs that minimize $\mathrm{O}_{2}$ crossover could be employed to promote rechargeability while maintaining large discharge capacities.

Finally, $\mathrm{Mg} / \mathrm{O}_{2}$ cells were discharged over a wide range of rates. The calculated Peukert exponent of 1.9 points to an $\mathrm{O}_{2}$-diffusionlimited discharge regime at rates higher than $0.02 \mathrm{~mA} \mathrm{~cm}^{-2}$. Compared to $\mathrm{Li} / \mathrm{O}_{2}$ cells, for which $k=1.6$, the $\mathrm{Mg} / \mathrm{O}_{2}$ cells examined here appear to exhibit lower rate capability.

\section{ASSOCIATED CONTENT}

Supporting Information is available free of charge on the ACS Publications website at DOI: 10/1021/acs.chemmater.xxxxxxx

\section{AUTHOR INFORMATION}

Corresponding Authors

*D.J.S.E-mail: djsiege@umich.edu.

${ }^{*}$ C.W.M. E-mail: charles.monroe@eng.ox.ac.uk.

Notes

The authors declare no competing financial interest.

\section{ACKNOWLEDGEMENTS}

DENSO International America, Inc. provided financial support for this work. D.J.S. acknowledges the Villum Foundation's Visiting Professor Program, the Nordea Foundation's Residence Program, and DTU Energy for support during his stay at DTU. J. S. Acknowledges partial support from the National Science Foundation, grant no. CBET1336387.
1. Aurbach, D.; Lu, Z.; Schechter, A.; Gofer, Y.; H., G.; Turgeman, R.; Cohen, Y.; Moshkovich, M.; Levi, E., Prototype systems for rechargeable magnesium batteries. Nature 2000, 407, 724-727.

2. Yoo, H. D.; Shterenberg, I.; Gofer, Y.; Gershinsky, G.; Pour, N.; Aurbach, D., Mg rechargeable batteries: an on-going challenge. Energy Environ. Sci. 2013, 6, 2265-2279.

3. Bucur, C. B.; Gregory, T.; Oliver, A. G.; Muldoon, J., Confession of a Magnesium Battery. The journal of physical chemistry letters 2015, 6, 3578-91.

4. Muldoon, J.; Bucur, C. B.; Gregory, T., Quest for nonaqueous multivalent secondary batteries: magnesium and beyond. Chemical reviews 2014, 114, 11683-720.

5. Matsui, M., Study on electrochemically deposited Mg metal. J. Power Sources 2011, 196, 7048-7055.

6. Watkins, T.; Kumar, A.; Buttry, D. A., Designer Ionic Liquids for Reversible Electrochemical Deposition/Dissolution of Magnesium. J Am Chem Soc 2016, 138, 641-50.

$7 . \quad$ Vardar, G.; Sleightholme, A. E.; Naruse, J.; Hiramatsu, H.; Siegel, D. J.; Monroe, C. W., Electrochemistry of magnesium electrolytes in ionic liquids for secondary batteries. ACS applied materials \& interfaces 2014, 6, 18033-9.

8. Kumar, N.; Siegel, D. J., Interface-Induced Renormalization of Electrolyte Energy Levels in Magnesium Batteries. The journal of physical chemistry letters 2016, 7, 874-881.
9. MacFarlane, D. R.; Forsyth, M.; Howlett, P. C.; Kar, M.; Passerini, S.; Pringle, J. M.; Ohno, H.; Watanabe, M.; Yan, F.; Zheng, W.; Zhang, S.; Zhang, J., Ionic liquids and their solid-state analogues as materials for energy generation and storage. Nature Reviews Materials 2016, $1,15005$.

10. Shterenberg, I.; Salama, M.; Gofer, Y.; Levi, E.; Aurbach, D., The challenge of developing rechargeable magnesium batteries. MRS Bulletin 2014, 39, 453-460.

11. Zu, C.-X.; Li, H., Thermodynamic analysis on energy densities of batteries. Energy Environ. Sci. 2011 , 4, 2614.

12. Radin, M. D.; Siegel, D. J., Non-Aqueous Metal-Air Batteries: Past, Present, and Future. In Rechargeable Batteries: Materials, Technologies and New Trends, Zhang, Z.; Zhang, S. S., Eds. Springer: Switzerland, 2015, p 511-539.

13. Hamlen, R. P.; Jerabek, E. C.; Ruzzo, J. C.; Siwek, E. G., Anodes for Refuelable Magnesium-Air Batteries. Journal of The Electrochemical Society 1969, 116, 1588.

14. Sathynarayana, S.; Munichandraiah, N., A new magnesiumair cell for long-life applications. J. Appl. Electrochem. 1981, 11, 33-39.

15. Li, W.; Li, C.; Zhou, C.; Ma, H.; Chen, J., Metallic magnesium nano/mesoscale structures: their shape-controlled preparation and mg/air battery applications. Angew Chem Int Ed Engl 2006, 45, 6009-12. 
16. Ma, Y.; Li, N.; Li, D.; Zhang, M.; Huang, X., Performance of $\mathrm{Mg}-14 \mathrm{Li}-1 \mathrm{Al}-0.1 \mathrm{Ce}$ as anode for Mg-air battery. J. Power Sources 2011, 196, 2346-2350.

17. Winther-Jensen, B.; Gaadingwe, M.; Macfarlane, D. R.; Forsyth, M., Control of magnesium interfacial reactions in aqueous electrolytes towards a biocompatible battery. Electrochimica Acta 2008, 53, 5881-5884.

18. Chen, L. D.; Nørskov, J. K.; Luntz, A. C., Theoretical Limits to the Anode Potential in Aqueous Mg-Air Batteries. The Journal of Physical Chemistry C 2015, 119, 19660-19667.

19. Song, G.; Atrens, A., Understanding Magnesium Corrosion-A Framework for Improved Alloy Performance. Advanced Engineering Materials 2003, 5, 837-858.

20. Zhang, T.; Tao, Z.; Chen, J., Magnesium-air batteries: from principle to application. Mater. Horiz. 2014, 1, 196-206.

21. Shiga, T.; Hase, Y.; Kato, Y.; Inoue, M.; Takechi, K., A rechargeable non-aqueous $\mathrm{Mg}-\mathrm{O} 2$ battery. Chem. Commun. (Camb) 2013, 49, 9152-4.

22. Shiga, T.; Hase, Y.; Yagi, Y.; Takahashi, N.; Takechi, K., Catalytic Cycle Employing a TEMPO-Anion Complex to Obtain a Secondary Mg-O2Battery. J. Phys. Chem. Lett. 2014, 5, 1648-1652.

23. Lu, Z.; Schechter, A.; Moshkovich, M.; Aurbach, D., On the electrochemical behavior of magnesium electrodes in polar aprotic electrolyte solutions. J. Electroanal. Chem. 1999, 466, 203-217.

24. Vardar, G.; Nelson, E. G.; Smith, J. G.; Naruse, J.; Hiramatsu, H.; Bartlett, B. M.; Sleightholme, A. E. S.; Siegel, D. J.; Monroe, C. W., Identifying the Discharge Product and Reaction Pathway for a Secondary $\mathrm{Mg} / \mathrm{O} 2 \mathrm{~B}$ attery. Chemistry of Materials 2015, 27, 7564-7568.

25. Nelson, E. G.; Brody, S. I.; Kampf, J. F.; Bartlett, B. M., A Magnesium Tetraphenylaluminate Battery Electrolyte Exhibits a Wide Electrochemical Potential Window and Reduces Stainless Steel Corrosion. J. Mater. Chem. A 2014.

26. Silverman, G. S.; Rakita, P. E., Handbook of Grignard reagents Marcel Dekker: New York, 1996; p 708.

27. Doe, R. E.; Han, R.; Hwang, J.; Gmitter, A. J.; Shterenberg, I.; Yoo, H. D.; Pour, N.; Aurbach, D., Novel, electrolyte solutions comprising fully inorganic salts with high anodic stability for rechargeable magnesium batteries. Chemical communications (Cambridge, England) 2014, 50, 243-5.

28. See, K. A.; Chapman, K. W.; Zhu, L.; Wiaderek, K. M.; Borkiewicz, O. J.; Barile, C. J.; Chupas, P. J.; Gewirth, A. A., The Interplay of $\mathrm{Al}$ and $\mathrm{Mg}$ Speciation in Advanced $\mathrm{Mg}$ Battery Electrolyte Solutions. J Am Chem Soc 2016, 138, 328-37.

29. Barile, C. J.; Nuzzo, R. G.; Gewirth, A. A., Exploring Salt and Solvent Effects in Chloride-Based Electrolytes for Magnesium Electrodeposition and Dissolution. The Journal of Physical Chemistry $C$ 2015, 119, 13524-13534.

30. Barile, C. J.; Barile, E. C.; Zavadil, K. R.; Nuzzo, R. G.; Gewirth, A. A., Electrolytic Conditioning of a Magnesium Aluminum Chloride Complex for Reversible Magnesium Deposition. The Journal of Physical Chemistry C 2014, 118, 27623-27630.

31. Guo, Y.; Yang, J.; NuLi, Y.; Wang, J., Study of electronic effect of Grignard reagents on their electrochemical behavior. Electrochemistry Communications 2010, 12, 1671-1673.

32. Griffith, L. D.; Sleightholme, A. E.; Mansfield, J. F.; Siegel, D. J.; Monroe, C. W., Correlating $\mathrm{Li} / \mathrm{O} 2$ cell capacity and product morphology with discharge current. ACS applied materials \& interfaces 2015, 7, 7670-8.

33. Kresse, G.; Furthmüller, J., Efficient iterative schemes for ab initio total-energy calculations using a plane-wave basis set. Physical Review B 1996, 1996, 11169-11186.

34. Kresse, G.; Hafner, J., Ab initio molecular dynamics for liquid metals. Physical Review B 1993, 47, 558-561.
35. Kresse, G.; Hafner, J., Ab initiomolecular-dynamics simulation of the liquid-metal-amorphous-semiconductor transition in germanium. Physical Review B 1994, 49, 14251-14269.

36. Blöchl, P. E., Projector augmented-wave method. Physical Review B 1994, 50, 17953-17979.

37. Perdew, J. P.; Burke, K.; Ernzerhof, M., Generalized Gradient Approximation Made Simple. Physical Review Letters 1996, 77, 3865-3868.

38. Dion, M.; Rydberg, H.; Schroder, E.; Langreth, D. C.; Lundqvist, B. I., van der Waals density functional for general geometries. Phys Rev Lett 2004, 92, 246401.

39. Roman-Perez, G.; Soler, J. M., Efficient implementation of a van der Waals density functional: application to double-wall carbon nanotubes. Phys Rev Lett 2009, 103, 096102.

40. Klimeš, J.; Bowler, D. R.; Michaelides, A., Van der Waals density functionals applied to solids. Physical Review B 2011, 83.

41. Liu, J. Characterizing Metal/Oxygen Batteries with Multiphase Continuum-Scale Models. $\mathrm{PhD}$ thesis, University of Michigan, 2015.

42. Lu, Y.-C.; Kwabi, D. G.; Yao, K. P. C.; Harding, J. R.; Zhou, J.; Zuin, L.; Shao-Horn, Y., The discharge rate capability of rechargeable Li-O2 batteries. Energy \& Environmental Science 2011, 4, 2999.

43. Quaranta, M.; Murkovic, M.; Klimant, I., A new method to measure oxygen solubility in organic solvents through optical oxygen sensing. The Analyst 2013, 138, 6243-5.

44. Johnson, L.; Li, C.; Liu, Z.; Chen, Y.; Freunberger, S. a.; Tarascon, J.-M.; Ashok, P. C.; Praveen, B. B.; Dholakia, K.; Bruce, P. $\mathrm{G}$., The role of $\mathrm{LiO} 2$ solubility in $\mathrm{O} 2$ reduction in aprotic solvents and its consequences for Li-O2 batteries. Nat. Chem. 2014, 6, 1091-1099.

45. Stern, K. H., High Temperature Properties and Decomposition of Inorganic Salts, Part 4. Oxy-Salts of the Halogens. Journal of Physical and Chemical Reference Data 1974, 3, 481-526.

46. Medeiros, M. G.; Dow, E. G., Magnesium-solution phase catholyte seawater electrochemical system. Journal of Power Sources 1999, 80, 78-82.

47. Canepa, P.; Jayaraman, S.; Cheng, L.; Rajput, N. N.; Richards, W. D.; Gautam, G. S.; Curtiss, L. A.; Persson, K. A.; Ceder, G., Elucidating the structure of the magnesium aluminum chloride complex electrolyte for magnesium-ion batteries. Energy Environ. Sci. 2015, 8, 3718-3730.

48. Radin, M. D.; Siegel, D. J., Charge transport in lithium peroxide: relevance for rechargeable metal-air batteries. Energy \& Environmental Science 2013, 6, 2370.

49. Radin, M. D.; Monroe, C. W.; Siegel, D. J., Impact of SpaceCharge Layers on Sudden Death in Li/O2 Batteries. The journal of physical chemistry letters 2015, 6, 3017-22.

50. NIST-JANAF Thermochemical Tables.

51. Mulder, W. H.; Sluyters, J. H.; Pajkossy, T.; Nyikos, L., Tafel current at fractal electrodes. Connection with admittance spectra. Journal of Electroanalytical Chemistry and Interfacial Electrochemistry 1990, 285, 103-115.

52. Leskes, M.; Moore, A. J.; Goward, G. R.; Grey, C. P., Monitoring the Electrochemical Processes in the Lithium-Air Battery by Solid State NMR Spectroscopy. The journal of physical chemistry. C, Nanomaterials and interfaces 2013, 117, 26929-26939.

53. $\quad$ Ren, X.; Lau, K. C.; Yu, M.; Bi, X.; Kreidler, E.; Curtiss, L. A.; $\mathrm{Wu}, \mathrm{Y}$., Understanding side reactions in $\mathrm{K}-\mathrm{O} 2$ batteries for improved cycle life. ACS applied materials \& interfaces 2014, 6, 19299307.

54. Schwenke, K. U.; Meini, S.; Wu, X.; Gasteiger, H. A.; Piana, M., Stability of superoxide radicals in glyme solvents for non-aqueous Li-O2 battery electrolytes. Physical chemistry chemical physics : PCCP 2013, 15, 11830-9. 
55. Zhang, T.; Zhou, H., A reversible long-life lithium-air battery in ambient air. Nat Commun 2013, 4, 1817.

56. Irvine, J. T. S.; Sinclair, D. C.; West, A. R., Electroceramics Characterization by Impedance Spectroscopy. Advanced Materials 1990, 2, 132-138.

57. Smith, J. G.; Naruse, J.; Hiramatsu, H.; Siegel, D. J., Theoretical Limiting Potentials in $\mathrm{Mg} / \mathrm{O} 2 \mathrm{Batteries}$. Chemistry of Materials 2016, 28, 1390-1401.

58. Doerffel, D.; Sharkh, S. A., A critical review of using the Peukert equation for determining the remaining capacity of lead-acid and lithium-ion batteries. Journal of Power Sources 2006, 155, 395-400.
59. Baert, D.; Vervaet, A., Lead-acid battery model for the derivation of Peukert's law. Electrochimica Acta 1999, 44, 3491-3504.

60. Adams, B. D.; Radtke, C.; Black, R.; Trudeau, M. L.; Zaghib, K.; Nazar, L. F., Current density dependence of peroxide formation in the Li-O2 battery and its effect on charge. Energy Environ. Sci. 2013, 6, 1772 .

61. Viswanathan, V.; Nørskov, J. K.; Speidel, A.; Scheffler, R.; Gowda, S.; Luntz, A. C., Li-O 2 Kinetic Overpotentials Tafel Plots from Experiment and First-Principles Theory. The journal of physical chemistry letters 2013, 4, 556-560.

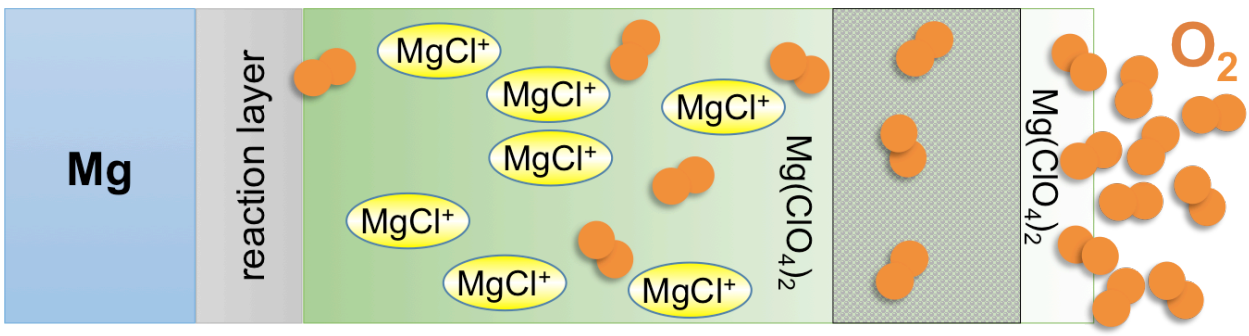

